\title{
Sorption and dissipation of aged metolachlor residues in eroded and rehabilitated soils
}

\section{Alegría Cabrera, ${ }^{\text {a }}$ Sharon K Papiernik, ${ }^{\text {b* }}$ William C Koskinenc and Pamela J Rice ${ }^{c}$}

\section{Abstract}

BACKGROUND: Sorption and dissipation of aged metolachlor were characterized in rehabilitated and eroded prairie soils using sequential batch slurry (conventional) and accelerated solvent extraction (ASE).

RESULTS: In spite of an almost twofold difference in soil organic carbon (OC) content, $S$-metolachlor sorption coefficients $\left(K_{d}\right)$ and dissipation rates $\left(\mathrm{DT}_{50}\right)$ were the same in soils from different landscape positions within an eroded landform. Soil was moved within the landform to increase productivity. In areas receiving topsoil addition, S-metolachlor $K_{d}$ was higher and DT 50 was longer than in eroded areas. The efficiency of extraction was higher for ASE than for conventional extractions. No consistent aging effect on $K_{d}$ was observed. Mineralization in 8 weeks accounted for $<10 \%$ of the applied metolachlor.

CONCLUSION: The results of this laboratory study support a field dissipation study. Both showed that S-metolachlor has the same retention and dissipation rate throughout an eroded landform, which was not expected owing to the large variability in soil properties, including OC concentrations. Altering soil properties by adding topsoil increased metolachlor sorption and persistence. The method of extraction (conventional versus ASE) affected calculated sorption coefficients and dissipation rates. In all cases, groundwater ubiquity scores (GUSs) categorized metolachlor as having intermediate mobility.

Published 2012 by John Wiley \& Sons, Ltd.

Keywords: metolachlor; sorption; aged residues; dissipation; ASE

\section{INTRODUCTION}

Long-term ( $\sim 100$ years) cultivation of hilly prairie landforms in the northern corn belt has resulted in eroded upper slope positions, with low organic carbon contents throughout the profile, and subsoil material close to the soil surface. Topsoil accumulation in areas of decreasing slope results in relatively high organic carbon throughout the upper profile and a large depth to the $\mathrm{C}$ horizon. ${ }^{1}$ In such landforms, crop yields are spatially variable, corresponding to the variation in soil properties. ${ }^{1-5}$

In eroded landforms, soil chemical and physical properties that influence herbicide fate are highly variable with landscape position, ${ }^{1,6}$ resulting in spatially variable sorption and degradation. Herbicide sorption coefficients in surface soil tend to correlate with organic carbon contents. This results in low sorption coefficients in upper slope positions that are low in organic carbon, and higher sorption coefficients in depressional areas where organic carbon contents are higher; backslope soil sorption coefficients have been observed to be intermediate between those in upper and lower slope positions. ${ }^{7-9}$ Pesticide degradation rates are also spatially variable in both surface soil and subsurface soil., 80,11 The rate of mineralization of several herbicides in surface soil was significantly faster in the upper slope than in the lower slope, ${ }^{8,11}$ presumably owing to lower sorption in the upper slope soils.

In addition to sorption-desorption and degradation processes being affected by properties of both the soils and pesticides, ${ }^{12,13}$ they are also influenced by soil-pesticide contact time (aging). ${ }^{14-17}$ Pesticides that persist in soils often become increasingly less available for leaching and degradation, as indicated by markedly declining rates of biodegradation with aging. ${ }^{17-20}$

One approach to increasing the overall productivity of eroded landscapes is soil-landscape rehabilitation, in which topsoil is moved from areas of net soil accumulation (areas of decreasing slope) to areas of net soil loss (convex landscape positions). Such intralandform soil movement can result in increased uniformity in soil properties across the landform and increased productivity in areas of soil addition. ${ }^{5}$ For instance, in the prairie pothole region of North America, soil-landscape rehabilitation increased grain yields by $10-90 \%$ in areas of soil addition compared with eroded hilltops. ${ }^{5,21}$

Management practices implemented to increase productivity, such as topsoil movement for soil-landscape rehabilitation, also affect physical and chemical properties of soils ${ }^{5,6}$ that may influence pesticide fate and behavior. The availability of agrochemicals for transport and degradation processes in soil

\footnotetext{
Correspondence to: Sharon K Papiernik, USDA-ARS, North Central Agricultural Research Laboratory, 2923 Medary Ave., Brookings, SD 57006, USA. E-mail:Sharon.Papiernik@ars.usda.gov

a Department of Soil, Water and Climate, University of Minnesota, St Paul, MN, USA

b USDA-ARS, North Central Agricultural Research Laboratory, Brookings, SD, USA

c USDA-ARS, St Paul, MN, USA
} 
is characterized by the partition coefficient $\left(K_{\mathrm{d}}\right)$, the ratio of agrochemical in the sorbed phase to that in the dissolved phase. Partition coefficients are traditionally determined by direct measurement with the slurry or batch method, which has a variety of disadvantages. ${ }^{13,22}$ Another method to determine sorption $K_{\mathrm{d}}$, particularly for aged residues, is a sequential batch slurry extraction in which soil is first extracted using a mild aqueous solvent, followed by a more vigorous organic solvent extraction. ${ }^{14-16,19}$ Highly efficient methods, such as accelerated solvent extraction (ASE), have been developed to extract aged pesticide residues from soil by varying the extraction solvent, temperature and pressure. ${ }^{23}$ In sequential extraction, the pesticide in the aqueous extract is taken as the solution concentration; this fraction is considered to be readily available for uptake, leaching and degradation. The organic solvent extract is considered to be the sorbed or 'potentially' available pesticide. ${ }^{17,18,20}$ Because it characterizes both the amount and the partitioning of agrochemicals in soil, sequential solvent extraction of aged samples can provide both sorption $\left(K_{\mathrm{d}}\right)$ and degradation $\left(\mathrm{DT}_{50}\right)$ data.

In this work, the $K_{d}$ was determined for aged residues of the chloroacetanilide herbicide $S$-metolachlor, using sequential batch slurry and ASE as extraction methods. Metolachlor is a selective herbicide used to control specific annual grasses and broadleaf weeds in agricultural crops, including corn, soybean, and sorghum. S-Metolachlor is the third most heavily used herbicide in the United States (14-16 million kg used in the agriculture sector in 2007) $)^{24}$ and is detected frequently in ground and surface water. $^{25-27}$ The overall objective was to determine the sorption and dissipation of aged S-metolachlor residues on eroded soils and those rehabilitated by soil movement. This information contributes to a better understanding of the effects of management practices on metolachlor sorption and dissipation, which is essential to characterize its weed control efficacy and availability for off-site transport.

\section{EXPERIMENTAL METHODS}

\subsection{Soils}

Soil cores were collected in June 2009 from a field near Morris, MN $\left(45.65^{\circ} \mathrm{N}, 95.83^{\circ} \mathrm{W}\right)$. The site was divided into six plots, and each plot was divided into six subplots according to the landscape position: summit, shoulder, upper backslope, lower backslope, footslope and toeslope. Three of the plots were rehabilitated in November 2005 by removing the top $15-20 \mathrm{~cm}$ of soil from the footslope and toeslope and adding $15-20 \mathrm{~cm}$ of soil to the surface of the summit, shoulder and upper backslope subplots, followed by tillage to $20-25 \mathrm{~cm}$ depth. The other three plots remained in their eroded condition (undisturbed). More details about the site can be found in Papiernik et al. ${ }^{5}$ Between 2005 and 2009, the site was cropped to soybean and corn, following standard local practices. $^{6}$

For this study, soil was collected from the upper $15 \mathrm{~cm}$ of the shoulder and footslope subplots of each of the six plots. These landscape positions were selected as being representative of eroded and depositional areas in this landform, avoiding the extremes on either end. Samples from replicated field plots were considered to be laboratory replicates as well, giving triplicate samples of four soils: rehabilitated shoulder, undisturbed shoulder, rehabilitated footslope and undisturbed footslope.

Soils were dried and sieved through a $2 \mathrm{~mm}$ mesh screen. Properties of the soils are shown in Table 1. Particle size analysis was done only before the rehabilitation; soil from the undisturbed shoulder was a clay loam, with $22 \pm 0.9 \%$ clay and $25 \pm 1.0 \%$ silt; soil from the undisturbed footslope was a sandy loam, with $19 \pm 1.2 \%$ clay and $26 \pm 1.1 \%$ silt. The concentration of organic carbon (OC) was higher in soil from the rehabilitated shoulder than in soil from the undisturbed shoulder, but there was no difference in OC in the footslope (Table 1).

\subsection{Chemicals}

S-Metolachlor [2-chloro- $N$-(2-ethyl-6-methylphenyl)- $N$-(2-methoxy-1-methylethyl) acetamide] (98\% purity) was purchased from Sigma-Aldrich (St Louis, MO). Uniformly ring-labeled $\left[{ }^{14} \mathrm{C}\right]$ metolachlor (2.02 MBq mg $\mathrm{mg}^{-1}$ and $99.2 \%$ radiochemical purity) was supplied by Syngenta. Solvents (methanol and acetonitrile, HPLC grade; dichloromethane, reagent ACS grade) were purchased from Fisher Scientific (Pittsburgh, PA) and were used as supplied.

\subsection{Metolachlor addition and incubation}

An aliquot of each soil sample (10 g dry weight) was weighed into a glass tube. S-Metolachlor (in methanol) was added to each soil sample to achieve a herbicide concentration of $1 \mu \mathrm{g} \mathrm{g}^{-1}$ with $84 \mathrm{~Bq}{ }^{14} \mathrm{C} \mathrm{g}^{-1}$. This is typical of surface soil concentrations of $S$ metolachlor following stand-alone application. After evaporation of the methanol $(\sim 1 \mathrm{~h})$, distilled water was added to the soil to reach a soil moisture content of $20 \%(\mathrm{w} / \mathrm{w})$. Glass wool was placed on the soil surface, and one vial containing $1 \mathrm{~mL}$ of $0.5 \mathrm{~N}$ $\mathrm{NaOH}$ was placed on the glass wool to trap the ${ }^{14} \mathrm{CO}_{2}$ formed from ${ }^{14} \mathrm{C}$-metolachlor mineralization. The tubes were capped, and soil samples were incubated in the dark at constant temperature $\left(25 \pm 1^{\circ} \mathrm{C}\right)$ for 0,2 or 8 weeks. Moisture was monitored weekly and adjusted when needed back to $20 \%$ with distilled water. The $\mathrm{NaOH}$ traps were replaced weekly. After trap removal, $5 \mathrm{~mL}$ of Ecolite scintillation cocktail was mixed with the $\mathrm{NaOH}$ and analyzed as described in Section 2.6.

\subsection{Conventional sequential extraction of metolachlor}

Soil samples were extracted by shaking overnight (>20 h) with $20 \mathrm{~mL}$ of $0.01 \mathrm{~N} \mathrm{CaCl}_{2}$ on a reciprocating shaker. After

Table 1. Selected properties of the shoulder and footslope soils

\begin{tabular}{|c|c|c|c|c|}
\hline & \multicolumn{2}{|c|}{ Shoulder } & \multicolumn{2}{|c|}{ Footslope } \\
\hline & Rehabilitated & Undisturbed & Rehabilitated & Undisturbed \\
\hline Organic carbon $\left(\mathrm{g} \mathrm{kg}^{-1}\right)$ & $34 \pm 2$ & $13 \pm 2$ & $23 \pm 3$ & $22 \pm 2$ \\
\hline $\mathrm{pH}$ in $\mathrm{CaCl}_{2}$ & $7.66 \pm 0.01$ & $7.73 \pm 0.04$ & $7.71 \pm 0.02$ & $7.69 \pm 0.01$ \\
\hline $\mathrm{EC}\left(\mu \mathrm{S} \mathrm{cm}^{-1}\right)$ & $330 \pm 14$ & $230 \pm 6$ & $270 \pm 12$ & $270 \pm 5$ \\
\hline Bulk density $\left(\mathrm{g} \mathrm{cm}^{-3}\right)$ & $1.22 \pm 0.03$ & $1.24 \pm 0.04$ & $1.39 \pm 0.09$ & $1.26 \pm 0.05$ \\
\hline
\end{tabular}


centrifugation at $370 \times g$ for $30 \mathrm{~min}$, the supernatant was removed. The volume of supernatant was measured, a $1 \mathrm{~mL}$ aliquot was mixed with $5 \mathrm{~mL}$ of Ecolite scintillation cocktail (MP Biomedicals, Solon, $\mathrm{OH}$ ) and the radioactivity was measured as described below. This provided a measurement of the $\mathrm{CaCl}_{2}$-extractable total ${ }^{14} \mathrm{C}$ (metolachlor and metabolites) in each sample. To determine the amount of parent metolachlor in the aqueous extract, the remaining aqueous supernatant was extracted twice with dichloromethane $(4: 1$ aqueous supernatant:dichloromethane, $\mathrm{v}: \mathrm{v})$, and the two extracts were mixed and evaporated with $\mathrm{N}_{2}$ just to dryness at $35^{\circ} \mathrm{C}$. The residues were dissolved with $1 \mathrm{~mL}$ acetonitrile: water $(10: 90 \mathrm{v}: \mathrm{v})$ and filtered with $0.45 \mu \mathrm{m}$ PTFE filters (Millipore, Billerica, MA). The samples were stored at $4{ }^{\circ} \mathrm{C}$ until analysis of metolachlor by HPLC as described in Section 2.6.

The soil was then extracted with $20 \mathrm{~mL}$ of acetonitrile: water (90:10 v:v) by shaking for $20 \mathrm{~h}$ on a reciprocating shaker. Samples were centrifuged at $370 \times g$ for $30 \mathrm{~min}$, and then the supernatant was removed and the volume measured. A $1 \mathrm{~mL}$ aliquot of the supernatant was mixed with $5 \mathrm{~mL}$ of Ecolite scintillation cocktail and the radioactivity was measured (to give acetonitrile-extractable ${ }^{14} \mathrm{C}$ ). To determine acetonitrileextractable metolachlor, the acetonitrile in the remaining extract was evaporated with $\mathrm{N}_{2}$ at $35^{\circ} \mathrm{C}$. Samples were passed through $0.45 \mu \mathrm{m}$ PTFE filters and stored at $4{ }^{\circ} \mathrm{C}$ until analysis of the parent herbicide by HPLC.

\subsection{Sequential accelerated solvent extraction (ASE) of metolachlor}

ASE extraction was performed using a Dionex ASE 300 accelerated solvent extractor (Sunnyvale, CA) equipped with $33 \mathrm{~mL}$ cells. Triplicate soil samples $(10 \mathrm{~g})$ were thoroughly mixed with $2.5 \mathrm{~g}$ of hydromatrix (used as drying and dispersing agent) and $15 \mathrm{~g}$ of quartz sand to completely fill the cell. Soil samples were first extracted for 15 min static equilibration with $0.01 \mathrm{~N} \mathrm{CaCl}_{2}$ at $10.3 \mathrm{MPa}$ pressure and $25^{\circ} \mathrm{C}$. The cells were rinsed with $30 \%$ of the extraction cell volume, the aqueous extracts were collected in $250 \mathrm{~mL}$ bottles and the volume was measured $(28-35 \mathrm{~mL})$. A second extraction was performed with acetonitrile: water $(90: 10$ $\mathrm{v}: \mathrm{v})$ using a static extraction time of $5 \mathrm{~min}$, a pressure of $10 \mathrm{MPa}$, an oven temperature of $100^{\circ} \mathrm{C}$ and a heat time of $5 \mathrm{~min}$. The cells were rinsed with $30 \%$ of the extraction cell volume, the extracts were collected in $250 \mathrm{~mL}$ bottles and the volume was measured (34-46 mL). Radioactivity and the concentration of metolachlor in each sample were determined as described for the conventional extraction.

\subsection{Analysis of ${ }^{14} \mathrm{C}$ and metolachlor \\ 2.6.1 ${ }^{14} \mathrm{C}$ in extracts}

Radioactivity in vials was counted for $10 \mathrm{~min}$ in a liquid scintillation counter (Tri-Carb 1500; Packard, Waltham, MA). Vials were kept in the dark overnight prior to analysis to reduce chemiluminescence.

\subsubsection{Metolachlor in extracts}

A Waters HPLC with a diode array detector and a Zorbax SB-C18 column (4.6 $6150 \mathrm{~mm}, 5 \mu \mathrm{m}$ film thickness) was used for analysis. The mobile phase was a gradient of $0.1 \%$ formic acid acetonitrile and purified water, starting at $10 \%$ acetonitrile and changing to $90 \%$ at $5 \mathrm{~min}$, remaining constant for $3 \mathrm{~min}$ and then decreasing to $10 \%$ acetonitrile at $11 \mathrm{~min}$. The flow rate was $1 \mathrm{~mL} \mathrm{~min}{ }^{-1}$. The injection volume was $50 \mu \mathrm{L}$. One fraction was collected from 0 to $5 \mathrm{~min}$, a fraction was collected every $30 \mathrm{~s}$ until $11 \mathrm{~min}$ and the last fraction was collected from 11 to $15 \mathrm{~min}$. Aliquots $(0.5 \mathrm{~mL})$ of each fraction were removed and mixed with $5 \mathrm{~mL}$ of Ecolite scintillation cocktail and analyzed by liquid scintillation counting to calculate the percentage of parent ${ }^{14} \mathrm{C}$-metolachlor in the extracts.

\subsubsection{Unextracted ${ }^{14} \mathrm{C}$ residues}

After extraction, the moisture content of each soil sample was determined. Soil ( $0.33 \mathrm{~g}$ dry weight) was combusted in a sample oxidizer (Packard 307; Packard, Waltham, MA). The ${ }^{14} \mathrm{CO}_{2}$ released from the oxidizer was chemically trapped (Carbo-Sorb $\mathrm{E}$ mixed with Permafluor V; PerkinElmer, Waltham, MA), and the ${ }^{14} \mathrm{C}$ was quantified by liquid scintillation counting, as described for ${ }^{14} \mathrm{C}$ in extracts.

\subsection{Sorption coefficients}

Sorption coefficients were calculated as $K_{d}=C_{s} / C_{e}$, where $C_{e}$ is the metolachlor concentration in the aqueous phase (extracted with $0.01 \mathrm{~N} \mathrm{CaCl}_{2}$ solution) and $C_{\mathrm{s}}$ is the metolachlor concentration in the sorbed phase (extracted with acetonitrile). Sorption coefficients were normalized to the fraction of organic carbon in the soil $\left(f_{\mathrm{OC}}\right)$ to give $K_{\mathrm{OC}}=\left(K_{\mathrm{d}} / f_{\mathrm{OC}}\right)$. Sorption coefficients were calculated separately for both ASE and conventional extraction of each soil at each incubation time.

The rate of dissipation of the extractable metolachlor was determined from the total extracted metolachlor (aqueous plus acetonitrile) at each incubation time. Dissipation rates were determined by fitting the total extractable metolachlor to a firstorder kinetic model $C=C_{0} \mathrm{e}^{-k t}$, where $C$ and $C_{0}$ are the amount of metolachlor extracted at time $=t$ and time $=0$ respectively, and $k$ is the decay coefficient. Dissipation half-lives (DT $\left.{ }_{50}\right)$ were calculated as $\mathrm{DT}_{50}=\ln (2) / k$.

The groundwater ubiquity score (GUS) was calculated to evaluate the predicted mobility of S-metolachlor in each soil. This index ${ }^{28}$ uses sorption and degradation rates to categorize the leaching potential of contaminants in soil: GUS $=\log \mathrm{DT}_{50} \times$ [ $4-\log K_{\mathrm{OC}}$ ]. Chemicals with GUS $<1.8$ may be considered as non-leachers, and those with GUS $>2.8$ as leachers. ${ }^{28}$

\subsection{Statistical analyses}

Two-sample $t$-tests were used to evaluate differences in $K_{d}$ and $K_{\mathrm{OC}}$ with extraction method (conventional extraction versus ASE) for the same soil and incubation time. One-way ANOVA and the Fisher's LSD test were used to evaluate differences in $K_{\mathrm{d}}$ and $K_{\mathrm{OC}}$ values for the four soils for fixed incubation time and extraction method. This analysis was also used to determine differences in $K_{\mathrm{d}}$ over time (aging effect) for the same soil and extraction method.

\section{RESULTS AND DISCUSSION}

\subsection{Metolachlor sorption and dissipation in eroded landform}

In both the shoulder and footslope of the eroded landform, $K_{d}$ of $S$-metolachlor was $3.1 \mathrm{~mL} \mathrm{~g}^{-1}$ in freshly spiked soil. In contrast to some previous reports for other herbicides, ${ }^{7-9}$ there was no significant difference in metolachlor sorption to undisturbed soils from the upper and lower slope (Table 2), in spite of an almost twofold difference in organic carbon content (Table 1). Although determined using a sequential solvent extraction method, these $K_{\mathrm{d}}$ values are within the range reported for metolachlor sorption coefficients determined by the batch equilibration procedure. ${ }^{29}$ The results of these studies suggest that soil characteristics (structure of native soil organic matter, presence of other sorbents) 
Table 2. S-metolachlor sorption coefficients and dissipation rates in rehabilitated and undisturbed soils, determined using ASE and conventional extraction. Sorption coefficients are for samples with no aging. Mineralization and unextracted ${ }^{14} \mathrm{C}$ are for samples incubated for 8 weeks. Values are the mean \pm standard error ${ }^{\mathrm{a}}$

\begin{tabular}{|c|c|c|c|c|c|}
\hline \multirow[b]{2}{*}{ Parameter } & \multirow[b]{2}{*}{ Extraction method } & \multicolumn{2}{|c|}{ Shoulder } & \multicolumn{2}{|c|}{ Footslope } \\
\hline & & Rehabilitated & Undisturbed & Rehabilitated & Undisturbed \\
\hline \multirow[t]{2}{*}{$K_{\mathrm{d}}\left(\mathrm{mL} \mathrm{g}^{-1}\right)^{\mathrm{b}}$} & Conventional & $5.4 \pm 0.9 a$ & $3.1 \pm 0.7 b$ & $3.5 \pm 0.1 \mathrm{~b}$ & $3.1 \pm 0.2 b$ \\
\hline & ASE & $9.0 \pm 0.6 \mathrm{a}$ & $7.1 \pm 0.7 \mathrm{~b}$ & $6.6 \pm 0.2 b$ & $5.8 \pm 0.2 b$ \\
\hline \multirow[t]{2}{*}{$K_{\mathrm{OC}}\left(\mathrm{mL} \mathrm{g}^{-1}\right)$} & Conventional & $160 \pm 25 a b$ & $237 \pm 50 a$ & $152 \pm 6 a b$ & $139 \pm 9 b$ \\
\hline & ASE & $266 \pm 17 b$ & $544 \pm 57 a$ & $286 \pm 9 b$ & $263 \pm 10 b$ \\
\hline \multirow[t]{2}{*}{$\mathrm{DT}_{50}$ (days) ${ }^{\mathrm{c}}$} & Conventional & $29(25-35) b$ & $15(13-17) a$ & $36(29-45) b$ & $15(12-20) a$ \\
\hline & ASE & $36(34-39) b$ & $26(23-30) a$ & $38(34-44) b$ & $26(23-29) a$ \\
\hline \multirow[t]{2}{*}{ Mineralization (\% of applied) } & Conventional & $3.7 \pm 0.1 \mathrm{~b}$ & $7.7 \pm 0.4 \mathrm{a}$ & $4.0 \pm 0.1 \mathrm{~b}$ & $7.0 \pm 0.1 \mathrm{a}$ \\
\hline & ASE & $4.0 \pm 0.1 \mathrm{~b}$ & $8.0 \pm 0.4 a$ & $3.9 \pm 0.1 b$ & $7.6 \pm 0.1 \mathrm{a}$ \\
\hline \multirow[t]{2}{*}{ Unextracted ${ }^{14} \mathrm{C}$ (\% of applied) } & Conventional & $46.3 \pm 0.8 a$ & $45.5 \pm 1 \mathrm{a}$ & $45.6 \pm 2 \mathrm{a}$ & $43.7 \pm 0.5 a$ \\
\hline & ASE & $32.1 \pm 3 \mathrm{a}$ & $30.0 \pm 4 \mathrm{a}$ & $31.9 \pm 4 a$ & $35.3 \pm 2 \mathrm{a}$ \\
\hline
\end{tabular}

are important in determining sorptivity, as discussed in Wauchope et al. ${ }^{13}$ Because the undisturbed shoulder soil had about half the OC content of the other soils, $K_{\mathrm{OC}}$ was highest in this eroded soil (Table 2). For freshly spiked soils, normalizing $K_{\mathrm{d}}$ values to the $f_{\mathrm{OC}}$ did not affect the variation in sorption coefficients.

For all samples, mineralization accounted for $<10 \%$ of the applied metolachlor within the first 8 weeks (Table 2), similar to previous reports. ${ }^{30}$ Metolachlor dissipated at the same rate in soil from the shoulder and footslope positions (Table 2). These $\mathrm{DT}_{50}$ values were similar to those of a field dissipation study ${ }^{31}$ conducted at the site from which the soils used in these laboratory studies were collected. In the field studies, which included a growing corn crop, $\mathrm{DT}_{50}$ values were 24-29 days, with no significant difference in dissipation rates among landscape positions. ${ }^{31}$ These laboratory tests confirm that, in spite of significant differences in soil properties, dissipation proceeded at approximately the same rate in soils from different landscape positions within an eroded landscape. Unlike some other studies, ${ }^{8,11}$ no differences in herbicide mineralization rates were observed between different landscape positions.

\subsection{Metolachlor sorption and dissipation in rehabilitated landform}

Sorption coefficients were generally higher in areas of addition of high-organic-matter topsoil (rehabilitated shoulder) as compared with undisturbed soil from the same landscape position, which is attributed to the greater OC content of the rehabilitated soil (Table 1). There was no difference in metolachlor $K_{d}$ values for the rehabilitated and undisturbed footslope soils, which had similar OC contents. Positive correlations between the soil organic matter content and the sorption of chloroacetanilide herbicides have been reported by others. ${ }^{32-35}$ The $K_{\mathrm{OC}}$ values for conventionally extracted samples with no aging averaged $170 \mathrm{~mL} \mathrm{~g}^{-1}$ (ranging from 140 to $240 \mathrm{~mL} \mathrm{~g}^{-1}$ ), which is consistent with previous reports for metolachlor sorption to a variety of soils. ${ }^{33,36,37}$ For eroded and rehabilitated soils there was no consistent significant increase in $K_{d}$ values between samples that were not aged and samples that were aged for 8 weeks. No statistically significant correlations were found between $K_{d}$ values and amount of chemical remaining or soil properties.

In general, the $\mathrm{DT}_{50}$ values found in these studies agree with those reported for field studies ${ }^{30,31,38-40}$ and laboratory studies ${ }^{29,35,40,41}$ under soil temperatures and moistures conducive to microbial degradation. For conventionally extracted samples, $\mathrm{DT}_{50}$ was shorter for undisturbed soils ( $\mathrm{DT}_{50}=15$ days) than for rehabilitated soils ( $\mathrm{DT}_{50}=30-40$ days). Mineralization in 8 weeks, although small, was significantly greater in eroded soils $(\sim 8 \%$ of the applied metolachlor) than in rehabilitated soils ( $\sim \%$ of the applied metolachlor) (Table 2). In these studies, metolachlor sorption coefficients were generally higher in rehabilitated soil than in undisturbed soil, and dissipation and mineralization tended to be slower in rehabilitated soil than in undisturbed soil (Table 2). Previous studies have shown that sorption of acetanilide herbicides to soil organic matter influences bioavailability, ${ }^{42}$ as it does for a variety of other classes of herbicides.

Using Gustafson's ${ }^{28}$ equation, calculated GUS values were significantly lower for the undisturbed shoulder (1.9) and footslope (2.2) soils compared with the rehabilitated shoulder (2.6) and footslope (2.8) soils. Based on GUS, the threat of metolachlor leaching is greater in upper slope areas of soil addition compared with the undisturbed (eroded) soil because metolachlor has a smaller $K_{\mathrm{OC}}$ and slower dissipation rate in rehabilitated shoulder soil (Table 2). For all treatments, GUS values for metolachlor classify it as intermediate between a non-leacher and leacher. These results are in basic agreement with the field dissipation study, which showed no differences in metolachlor leaching or dissipation in rehabilitated and undisturbed soils. ${ }^{31}$

\subsection{Accelerated solvent extraction of metolachlor}

Recoveries for the sequential extraction (aqueous followed by acetonitrile) were consistently higher for the ASE than for the conventional extraction (Fig. 1). For samples with no aging (time $=0$ ), conventional extraction recovered $\sim 80 \%$ of the metolachlor added to the soil, whereas ASE recovered $>95 \%$ (Fig. 1). At time 0, the conventional extraction and ASE removed the same amount of metolachlor during the aqueous extraction, but 

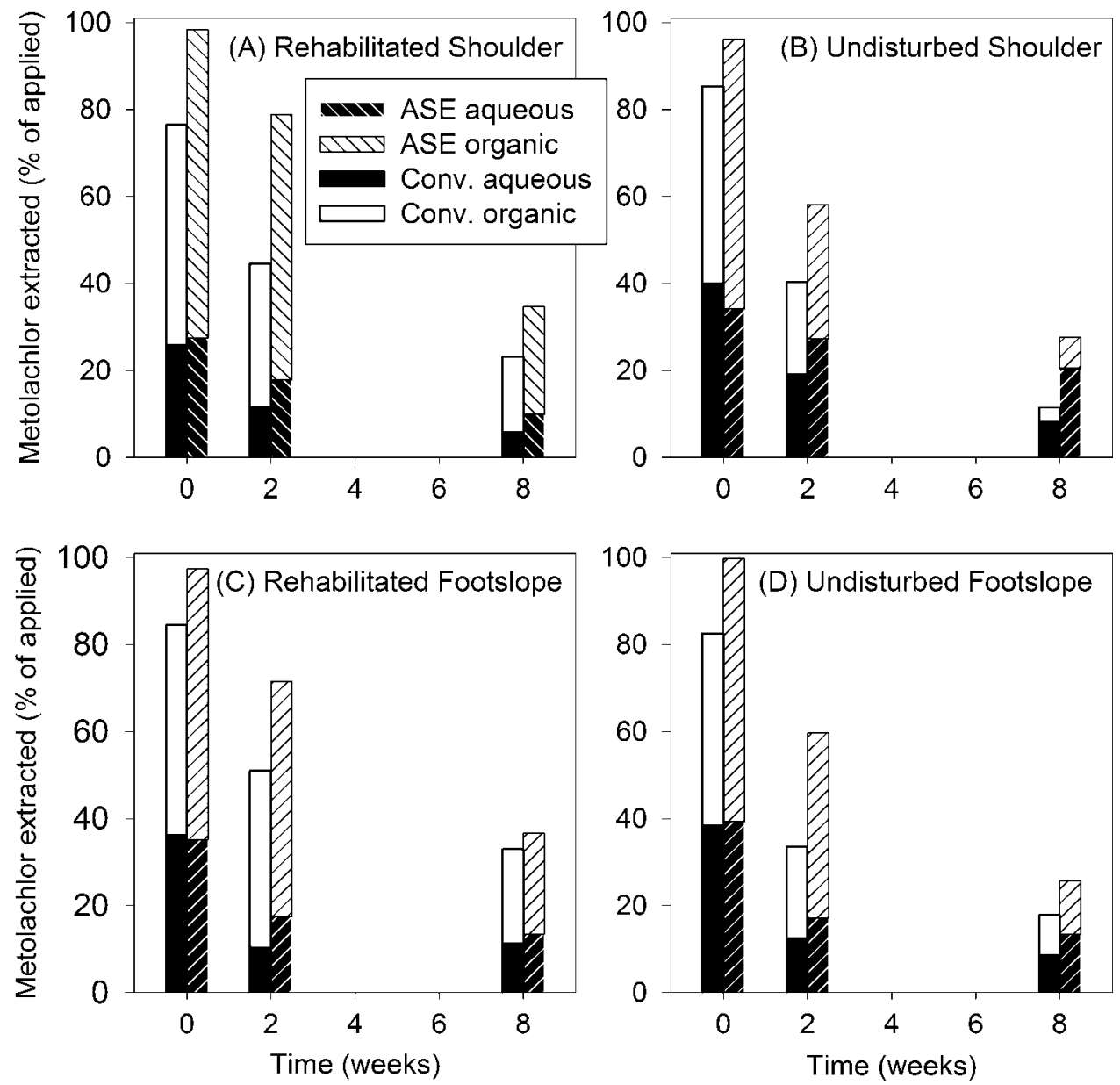

Figure 1. Fraction of metolachlor extracted with aqueous and organic solvent using ASE and conventional extraction: (A) rehabilitated shoulder; (B) undisturbed shoulder; (C) rehabilitated footslope; (D) undisturbed footslope.

ASE removed more metolachlor during the acetonitrile extraction (Fig. 1). The differences in extraction efficiency affected sorption coefficients. For samples with no aging (time $=0$ ), metolachlor sorption coefficients were consistently significantly lower for the conventional extraction than for the ASE extraction (Table 2). These results suggest that, at least in some cases, measured $K_{\mathrm{d}}$ values can be dependent on the method used to extract pesticide residues.

Similar differences in extraction efficiency were also observed at other incubation times (Fig. 1). In samples incubated for 2 or 8 weeks before extraction, ASE removed an average of $60 \%$ more metolachlor than conventional extractions in both the aqueous and acetonitrile extracts. This generated higher $C_{\mathrm{s}}$ and $C_{\mathrm{e}}$ values, so, for samples aged for 2 or 8 weeks, there was no significant difference in $K_{d}$ values for the conventional extraction and ASE. The present results concur with previous reports that ASE can remove a higher proportion of metolachlor residues from soil than conventional extraction, especially from aged samples..$^{23}$ Because of these differences in extraction efficiency, samples extracted using ASE generated longer $\mathrm{DT}_{50}$ values than the same samples extracted conventionally (Table 2). The higher $K_{\mathrm{OC}}$ and DT 50 values calculated for ASE samples resulted in GUS scores that were up to $15 \%$ lower for ASE than for conventional extractions, but this did not affect the GUS classification of metolachlor (intermediate between leacher and non-leacher).

For both extraction methods, the mass balance of ${ }^{14} \mathrm{C}$ (the sum of aqueous- and acetonitrile-extractable ${ }^{14} \mathrm{C}$, mineralized ${ }^{14} \mathrm{C}$ and unextracted ${ }^{14} \mathrm{C}$ ) ranged from 90 to $110 \%$. Unextracted ${ }^{14} \mathrm{C}$ residues in soil increased with time during the study. Unextracted residues at 8 weeks after conventional extraction accounted for about $45 \%$ of the ${ }^{14} \mathrm{C}$ added to the soil, significantly greater than for ASE ( $\sim 32 \%)$ because of the lower efficiency of manual extraction (Table 2). The formation of soil-bound residues has been shown by others to be important in metolachlor dissipation. ${ }^{30,43}$

\section{CONCLUSIONS}

Recent field studies have demonstrated that adding topsoil to eroded landforms can increase productivity ${ }^{5}$ without affecting the rate of metolachlor dissipation or weed control provided by metolachlor application. ${ }^{31}$ The field results were supported by these laboratory studies. Metolachlor exhibited the same sorption and dissipation rate in the upper slope and lower slope of an eroded landform, in spite of an almost twofold difference in organic carbon content between these two landscape positions. Metolachlor $K_{d}$ was higher in rehabilitated soil than in eroded soil from the upper slope, and the rate of metolachlor dissipation was slower in rehabilitated soil. Aggressive extraction conditions (elevated temperature and pressure in ASE) removed a higher proportion of sorbed metolachlor, which affected calculated distribution coefficients, dissipation rates and predicted leaching. The environmental significance of the varying strengths of pesticide binding to soil requires additional investigation. 


\section{ACKNOWLEDGEMENTS}

Technical assistance was provided by Brian Barber. Mention of trade names or commercial products in this publication is solely for the purpose of providing specific information and does not imply recommendation or endorsement by the US Department of Agriculture. USDA is an equal opportunity provider and employer.

\section{REFERENCES}

1 Papiernik SK, Lindstrom MJ, Schumacher TE, Schumacher JA, Malo DD and Lobb DA, Characterization of soil profiles in a landscape affected by long-term tillage. Soil Tillage Res 93:335-345 (2007).

2 Verity GE and Anderson DW, Soil-erosion effects on soil quality and yield. Can J Soil Res 70:471-484 (1990).

3 Schumacher TE, Lindstrom MJ, Schumacher JA, Lemme GD and Mokma DL, Modeling spatial variation in productivity due to tillage and water erosion. Soil Tillage Res 51:331-339 (1999).

4 Papiernik SK, Lindstrom MJ, Schumacher JA, Farenhorst A, Stephens KD, Schumacher TE, et al, Variation in soil properties and crop yield across an eroded prairie landscape. J Soil Water Conserv 60:388-395 (2005).

5 Papiernik SK, Schumacher TE, Lobb DA, Lindstrom MJ, Lieser ML, Eynard A, et al, Soil properties and productivity as affected by topsoil movement within an eroded landform. Soil Tillage Res 102:67-77 (2009).

6 Papiernik SK, Koskinen WC and Yates SR, Solute transport in eroded and rehabilitated prairie landforms. 1. Nonreactive solute. J Agric Food Chem 57:7427-7433 (2009).

7 Gaultier J, Farenhorst A and Crow G, Spatial variability of soil properties and 2,4-D sorption in a hummocky field as affected by landscape position and soil depth. Can J Soil Sci 86:89-95 (2006).

8 Liu Z, Clay SA and Clay DE, Spatial variability of atrazine and alachlor efficacy and mineralization in an eastern South Dakota field. Weed Sci 50:662-671 (2002).

9 Novak JM, Moorman TB and Cambardella CA, Atrazine sorption at the field scale in relation to soils and landscape position. J Environ Qual 26:1271-1277 (1997).

10 Charnay MP, Tuis S, Coquet $Y$ and Barriuso E, Spatial variability in ${ }^{14} \mathrm{C}$ herbicide degradation in surface and subsurface soils. Pest Manag Sci 61:845-855 (2005).

11 Gaultier JD and Farenhorst A, 2,4-D mineralization in soil profiles of a cultivated hummocky landscape in Manitoba, Canada. J Environ Sci Health Part B 42:255-264 (2007).

12 Koskinen WC and Harper SS, The retention process: mechanisms, in Pesticides in the Soil Environment, ed. by Cheng $\mathrm{HH}$. Soil Science Society of America, Madison, WI, pp. 51-77 (1990).

13 Wauchope RD, Yeh S, Linders JBHJ, Kloskowski R, Tanaka K, Rubin B, et al, Pesticide soil sorption parameters; theory, measurement, uses, limitations and reliability. Pest Manag Sci 58:419-445 (2002).

14 Cox L, Koskinen WC and Yen PY, Changes in sorption of imidacloprid with incubation time. Soil Sci Soc Am J 62:342-347 (1998).

15 Koskinen WC, Cox L and Yen PY, Changes in sorption/bioavailability of imidacloprid metabolites in soil with incubation time. Biol Fert Soils 33:546-550 (2001).

16 Koskinen WC, Rice PJ, Anhalt JA, Sakaliene O, Moorman TB and Arthur EL, Sorption-desorption of 'aged' sulfonylaminocarbonyltriazolinone herbicides in soil. J Agric Food Chem 50:5368-5372 (2002).

17 Barriuso E, Koskinen WC and Sadowsky MJ, Solvent extraction characterization of bioavailability of atrazine residues in soil. J Agric Food Chem 52:6552-6556 (2004).

18 Regitano JB, Koskinen WC and Sadowsky MJ, Influence of soil aging on sorption and bioavailability of simazine. J Agric Food Chem 54:1373-1379 (2006).

19 Regitano JB and Koskinen WC, Characterization of nicosulfuron availability in aged soils. J Agric Food Chem 56:5801 - 5806 (2008).

20 Trigo C, Koskinen WC, Celis R, Sadowsky MJ, Hermosin MC and Cornejo J, Bioavailability of organoclay formulations of atrazine in soil. J Agric Food Chem 58:11 857-11 863 (2010).
21 Smith DM, Lobb DA, Schumacher TE, Papiernik SK and Lindstrom MJ, Using landscape restoration to increase crop yield and improve soil quality on severely eroded hilltops in southwestern Manitoba. Proc Manitoba Soil Sci Soc, Winnipeg, Manitoba, Canada, pp. 109-119 (2009).

22 Kah $\mathrm{M}$ and Brown CD, Changes in pesticide adsorption with time at high soil to solution ratios. Chemosphere 68:1335-1343 (2007).

23 Gan J, Papiernik SK, Koskinen WC and Yates SR, Evaluation of accelerated solvent extraction (ASE) for pesticide residues analysis in soil. Environ Sci Technol 33:3249-3253 (1999).

24 Grube A, Donaldson D, Kiely T and Wu L, Pesticide Industry Sales and Usage, 2006 and 2007 Market Estimates. [Online]. Available: http://www.epa.gov/opp00001/pestsales/07pestsales/market estimates2007.pdf [10 August 2011].

25 Barbash JE, Thelin GP, Kolpin DW and Gilliom RJ, Major herbicides in ground water: results from the National Water-Quality Assessment. J Environ Qual 30:831-845 (2001).

26 Gilliom RJ, Pesticides in U.S. streams and groundwater. Environ Sci Technol 4:3408-3414 (2007).

27 Thurman EM, Goolsby DA, Meyer MT and Kolpin DW, Herbicides in surface waters of the Midwestern United States: the effect of spring flush. Environ Sci Technol 25:1794-1796 (1991).

28 Gustafson DI, Groundwater ubiquity score: a simple method for assessing pesticide leachability. Environ Toxicol Chem 8:339-357 (1989).

29 Shaner DL, Brunk G, Belles D, Westra P and Nissen S, Soil dissipation and biological activity of metolachlor and $S$-metolachlor in five soils. Pest Manag Sci 62:617-623 (2006).

30 LeBaron HM, McFarland JE, Simoneaux BJ and Ebert E, Metolachlor, in Herbicides: Chemistry, Degradation, and Mode of Action. Vol. 3, ed. by Kearney PC and Kaufman DD. Marcel Dekker, New York, NY, pp. 335-382 (1988).

31 Papiernik SK, Koskinen WC and Yates SR, Solute transport in eroded and rehabilitated prairie landforms. 2. Reactive solute. J Agric Food Chem 57:7434-7439 (2009).

32 Burgard DJ, Koskinen WC, Dowdy RH and Cheng HH, Metolachlor distribution in a sandy soil under irrigated potato production. Weed Sci 41:648-655 (1993).

33 Liu W, Gan J, Papiernik SK and Yates SR, Structural influences in relative sorptivity of chloracetanilide herbicides on soil. J Agric Food Chem 48:4320-4325 (2000).

34 Farenhorst A, Importance of soil organic matter fractions in soillandscape and regional assessments of pesticide sorption and leaching in soil. Soil Sci Soc Am J 70:1005-1012 (2006).

35 Si Y, Takagi K, Iwasaki A and Zhou D, Adsorption, desorption and dissipation of metolachlor in surface and subsubfarce soils. Pest Manag Sci 65:956-962 (2009).

36 Pignatello JJ and Huang LQ, Sorptive reversibility of atrazine and metolachlor residues in field soil samples. JEnviron Qual 20:222-228 (1991).

37 Peter CJ and Weber JB, Adsorption, mobility, and efficacy of alachlor and metolachlor as influenced by soil properties. Weed $\mathrm{Sci}$ 33:874-881 (1985).

38 Bowman BT, Mobility and persistence of metolachlor and aldicarb in field lysimeters. J Environ Qual 17:689-694 (1988).

39 Dinelli G, Accinelli C, Vicari A and Catizone P, Comparison of the persistence of atrazine and metolachlor under field and laboratory conditions. J Agric Food Chem 48:3037-3043 (2000).

40 Shaner DL and Henry WB, Field history and dissipation of atrazine and metolachlor in Colorado. J Environ Qual 36:128-134 (2007).

41 Zimdahl RL and Clark SK, Degradation of three acetanilide herbicides in soil. Weed Sci 30:545-548 (1982).

42 Stamper DM and Tuovinen $\mathrm{OH}$, Biodegradation of the acetanilide herbicides alachlor, metolachlor, and propachlor. Critical Rev Microbiol 24:1 - 22 (1998).

43 Rice PJ, Anderson TD and Coats JR, Degradation and persistence of metolachlor in soil: effects of concentration, soil moisture, soil depth, and sterilization. Environ Toxicol Chem 21:2640-2648 (2002). 